\title{
Two New Cists Tombs from Skamneli, Epirus, NW Greece
}

\author{
Eleni Vasileiou, Paraskevi Yiouni and Nikos Choinas* \\ Ephorate of Antiquities of Ioannina, Greece
}

Submission: November 05, 2018; Published: November 14, 2018

${ }^{*}$ Corresponding author: Eleni Vasileiou, Ephorate of Antiquities of Ioannina, Plateia 25 $5^{\text {th }}$ March 6, 45221, Ioannina, Greece

Abstract

In this review we will briefly present two new cist tombs of the end of Bronze Age discovered at the village Skamneli in the region of Epirus (NW Greece). The research is focused on two main areas: typological and cultural analysis and anthropological study in order to trace relations with the adjacent areas and to clarify aspects of mobility, status and gender.

Keywords: Skamneli; Cist tomb; Bronze jewelry; Handmade pottery; Amber; Central Europe; Mobility; Trade; Status; Exogamy

\section{Introduction}

The summer of 2016 at the village Skamneli (Ioannina, Greece) an undisturbed cist tomb (Grave 1), made by four large well-dressed sandstones, was located by a group of locals. Not far from it, a second, plundered, cist tomb (Grave 2) came to light.

Grave 1 [Dimensions: $1.78 \mathrm{~m}$ (long) X 0.40 (East Side) $0.43 \mathrm{~m}$ \{West Side) (width) X $0.26-0.30 \mathrm{~m}$. (South side) and $0.23-0.29 \mathrm{~m}$. (North side) (depth), was orientated SE-NW and contained two skeletons (a male and a female) in an extended antithetical position. The lower half of the female skeleton, which appears to have been placed in the grave in a second phase, was undisturbed, while the bones of the older male dead were heavily disturbed. The tomb was furnished with: an armlet of bronze wire with spiralling ends, a bronze anklet with a central rib and double spiral elements, several bronze rings, a bronze wheel-headed pin (Length: $17.5 \mathrm{~cm}$ ), two bronze elongated horseshoe-shaped objects and a significant number of beads made of various materials (crystal, chalcedony, faience, amber). From the tomb's deposit fragments of:a matt painted jug, of a wide mouth jar with plastic decoration, of a cup and of an unpainted cantharus were collected together with a few handmade sherds. The jewelry form part of the central European inspired tradition which characterizes many objects coming from cist tombs in the region of Zagori.

Grave 2 [Dimensions: 2.38m. (length) X $0.59-0.66 \mathrm{~m}$. (width) X $0.70-0.90 \mathrm{~m}$. (depth)], had an E-W orientation and it was found empty. Outside the tomb, next to the southern side, a small quantity of handmade, unpainted red orange sherds was gathered.
The cist is the most common type of grave used in Epirus during the end of the Bronze Age [1]. There has not been yet discovered an organized cemetery of the Bronze Age period. Clusters of cist tombs are located in four geographical units: the basin of Ioannina, the region of Zagori-Kalamas, the valley of the river Gormos in Pogoni and the valley of Konitsa [2]. In the wider region of Zagori and Kalamas, a significant number of Late Bronze Age graves (Elafotopos, Kato Pedina, Kalpaki, Mazaraki, Kapesovo) have been identified, which in some cases appear to have been small cemeteries (Elafotopos, Kalpaki, Mazaraki) [3]. The tombs contained 1 to 3 skeletons (men, women and children) and were furnished with bronze and clay vases, bronze jewelry (bracelets, rings, earrings, pins), beads of various materials (bronze, faience, amber) and bronze weapons (swords, daggers, spearheads, knives). Inhumation is the only practice preserved [4].

Multiple burials indicate respect for kinship ties and a tendency to display collective identities. The presence of "exotic" objects from neighboring areas (southern Greece, Balkans and central Europe) undoubtedly gives to the dead a superior social status [5]. In the valley of Kalpaki the natural passageways to the areas of Ioannina, Zagori, Pogoni, Konitsa and Kalamas are crossed, facilitating the entry from the northern part of Epirus and vice versa. The relatively large number of bronze objects and beads of various materials imply the presence of social groups that not only owned them but also participated in the procurement processes of raw materials and were involved in expanded networks where they gained ground and alliances and greatly strengthened their social role [6]. 
The location of the graves in the wider Kalamas river area may be associated with the appearance of a group of powerful people (traders or shepherds / warriors) in the local community, which has taken its power from the ability to control the accesses and movement of the aforementioned "exotic" objects [7]. Particularly attractive is the interpretation of several objects ("Mycenaean" and "Central European") as marriage products for the purpose of alliances [8].The anthropological study of the two skeletons will hopefully offer us important information about the origin of the dead's, the living conditions of the human groups lived in the area and the rate of their mobility.

\section{Acknowledgement}

We would like to warmly thank Mr Dimitrios Tsoumanis who indicated the tomb to our Service and both him and his father Athanassios for offering volunteer work to the excavation of the tombs. Many thanks also to the photographer of the Ephorate Panagiotis Tsigoulis and to the conservators George Kyrkos and Melina Naka. Special thanks finally to the anthropologist Dr Efrossini Vika for the attribution of the skeletons to a man and a woman respectively.

\section{References}

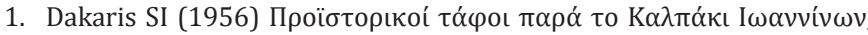
Archaiologiki Ephimerida 1956, pp.114-153; Papadopoulos Th (1987) 1987. Tombs and burial customs in Late Bronze Age Epirus In: Laffineur RL (Eds.), Thanatos. Les coutumes funéraires en Egée à l'âge du Bronze». Actes du colloque de Liège, 21-23 avril 1986, Aegeum

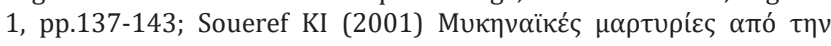
'Hлєıро; Tartaron TF and Zachos K [1999] The Mycenaeans and Epirus. In: The Mycenaean Periphery. Proceedings of the 1st International

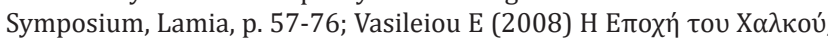

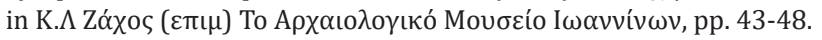

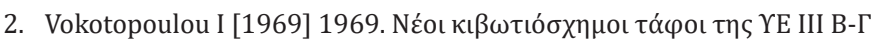

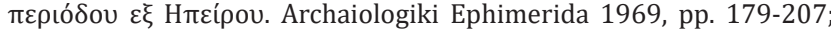
Andréou, E et Andréou, I [1987] Une nécropole tumulaire à Pogoni de l'Épire, in P. Cabanes (ed) L'Illyrie méridionale et l'Épire dans l'antiquité. Actes du colloque international de Clermont-Ferrand (2225 octobre 1984), Clermont- Ferrand,pp. 47-49.

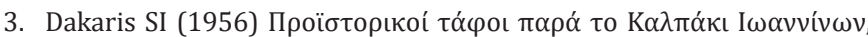
Archaiologiki Ephimerida 1956, pp.114-153; Vokotopoulou I (1969)

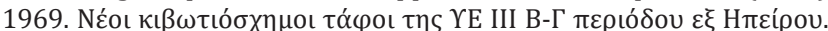
Archaiologiki Ephimerida 1969, pp. 179-207.

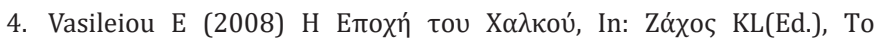

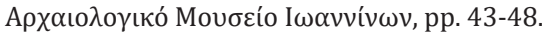

5. Binford LR (1971) Mortuary Practices: Their Study and Their Potential. Approaches to the Social Dimensions of Mortuary Practices, Memoirs of the Society for American Archaeology 25; Goldstein L (1981) Onedimensional archaeology and multi-dimensional people: Spatial organization and mortuary analysis. In: Chapman R, Kinnes I,Randsborg K (Eds.), The Archaeology of Death, Cambridge: Cambridge University Press, pp.53-70; Harding A (2015) The emergence of elite identities in Bronze Age Europe, $\sigma \tau$ o Origini. Prehistory and Protohistory of ancient civilizations XXXVIII 2015.2: 111-121.

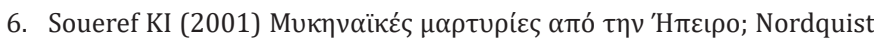
G (2002) Intra- and extramural, single and collective-burials in the Middle and Late Helladic periods, In: A new research on old material from Asine and Berbati in celebration on the fiftieth anniversary of the Swedish institute at Athens, Stockholm 2001, p. 23-29.

7. Feuer B (1983) The Northern Mycenaean Border in Thessaly, British Archaeological Reports International Series No. 176, Oxford; Kristiansen K and Larsson T (2005) The Rise of Bronze Age Society: travels, transmissions and transformations. Cambridge: Cambridge

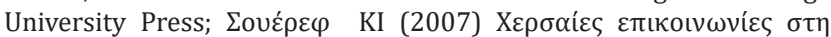

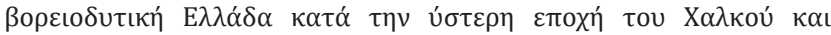

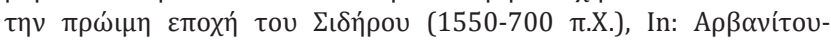

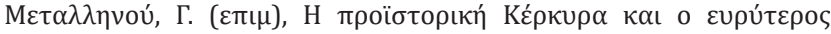

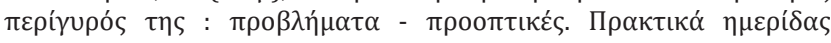

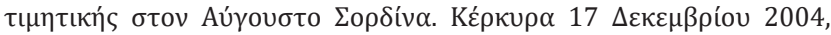

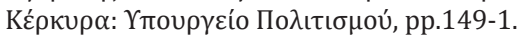

8. Kristiansen K, Allentoft ME, Frei KM, Iversen R, Johannsen NN, et al.(2017) Re-theorising mobility and the formation of culture and language among the Corded Ware Culture in Europe, Antiquity 91 (2017), pp. 334-347; Frei K.M, Mannering U, Kristiansen K, Allentoft M.E, Wilson A.S, Skals I, Tridico S, Nosch M.L, Willerslev E, Clarke L and Frei R (2015) Tracing the life story of a Bronze Age girl with high societal status, Nature Scientific Report 5, no.10431.

\section{Your next submission with Juniper Publishers will reach you the below assets}

- Quality Editorial service

- Swift Peer Review

- Reprints availability

- E-prints Service

- Manuscript Podcast for convenient understanding

- Global attainment for your research

- Manuscript accessibility in different formats

( Pdf, E-pub, Full Text, Audio)

- Unceasing customer service

Track the below URL for one-step submission https://juniperpublishers.com/online-submission.php 